\title{
HUBUNGAN KOMUNIKASI INSTRUKSIONAL DENGAN HASIL BELAJAR ILMU UKUR TANAH DI SMK NEGERI 1 JAKARTA
}

\author{
Agung Arianto ${ }^{1}$, Tuti Iriani ${ }^{2}$, Riyan Arthur ${ }^{3}$ \\ ${ }_{1,2,3}$ Universitas Negeri Jakarta \\ 1agungrnto@gmail.com, ${ }^{2}$ tutiiriani@unj.ac.id, ${ }^{3}$ arthur@unj.ac.id
}

\author{
Diterima : 22 Agustus 2018 \\ Direvisi : 23 Januari 2019 \\ Diterbitkan : 28 Februari 2019 \\ DOI $\quad:$ https://doi.org/10.21009/jpensil.v8i1.8481
}

\begin{abstract}
This study aims to determine the correlation between teacher's instructional communication and learning outcomes in the form of final exam in the subjects of Class X Land Measurement Science expertise in Modeling and Building Information expertise program at SMKN 1 Jakarta. The type of research used in this study is associative quantitative research. The method used is a survey method with a correlational approach. The population in this study were class X students of the Permodean Design and Building Information program at SMK 1 Jakarta, as many as 102 people. The sample in this study used the Random Sampling technique which was tested on 80 students.

The results showed that there was a positive and significant relationship between instructional communication and learning outcomes as evidenced by: correlation coefficient value of 0.601 which is included in the category of strong relationships, the significance value of the correlation coefficient $t$ count $=6.851$ and $t$ table $=1.991$ which indicates a significant relationship, and the relationship between instructional communication and final exam learning outcomes is obtained by the determination coefficient value of 0.376 . So the instructional communication factor can influence learning outcomes, which is 37.6\%, and the rest is influenced by other factors beyond instructional communication skills.
\end{abstract}

Keywords: instructional communication, learning outcomes.

\section{Pendahuluan}

Dunia pendidikan terus mengalami perkembangan seiring dengan tantangan yang dihadapi, salah satunya mampu menghasilkan individu yang berkualitas agar dapat bersaing di era global saat ini. Untuk itu, perlu adanya subjek yang dapat memfasilitasi agar pendidikan menjadi sebuah proses yang efektif dan efisien serta dapat mengantarkan peserta didik pada tujuan yang diharapkan (goals expectation). Salah satu subjek yang lekat dikenal adalah guru.

Guru merupakan ujung tombak dalam meningkatkan kualitas pendidikan, di mana guru akan melakukan interaksi langsung dengan peserta didik dalam pembelajaran di ruang kelas. Melalui proses belajar dan mengajar inilah berawalnya kualitas pendidikan. Artinya, secara keseluruhan kualitas pendidikan berawal dari kualitas pembelajaran yang dilaksanakan oleh guru di ruang kelas (Rosita \& Alfarisa, 2015: 673).

Pembelajaran yang tidak efektif merupakan salah satu penyebab hasil belajar yang rendah. Hasil belajar diapat setelah siswa menerima pengalaman belajarnya. Setiap proses belajar mengajar, keberhasilannya diukur dari seberapa hasil belajar yang dicapai siswa. Karena, hasil belajar merupakan bagian penting dalam proses pendidikan dan pengajaran. Tujuan hasil belajar yaitu untuk melihat sejauh mana kemampuan yang telah dicapai siswa 
dalam mengikuti proses belajar mengajar. Namun, hasil belajar yang rendah masih saja menjadi masalah sampai saat ini. Salah satu contohnya, terlihat pada nilai ulangan tengah semester ilmu ukur tanah kelas X program keahlian Desain Permodelan Informasi dan Bangunan (DPIB) di SMK Negeri 1 Jakarta tahun ajaran 2017/2018. Pada grafik lingkaran berikut, menunjukkan bahwa sebanyak $59 \%$ siswa belum mampu memenuhi standar ketuntasan minimal (KKM) sekolah.

Menurut Sukmadinata \& Nana (2005) dalam (Afriana dkk., 2018: 105) mengatakan bahwa hasil belajar dapat tercapai apabila dalam interaksi harus didukung dengan komunikasi yang jelas selama proses pembelajaran. Seorang guru yang tidak mampu berkomunikasi dengan jelas maka hasil belajar yang didapat juga tidak akan optimal. Komunikasi yang jelas mempunyai tujuan agar siswa menjadi mudah memahami setiap informasi dan tujuan belajarnya. Kemampuan komunikasi guru sudah diatur dalam Undang-Undang Republik Indonesia Nomor 14 Tahun 2005 yang mengatakan bahwa kemampuan untuk melakukan komunikasi yang efektif merupakan salah satu kompetensi yang harus dimiliki dan dikuasai oleh seorang guru. Jadi, dalam proses pembelajaran perlu adanya komunikasi belajar guru yang baik dan jelas untuk meningkatkan hasil belajar siswa. Komunikasi yang tidak jelas akan membawa akibat terhadap pesan atau materi yang disampaikan oleh guru (Sanjaya, 2016: 98).

Di SMK Negeri 1 Jakarta, mata pelajaran ilmu ukur tanah memiliki porsi jam pelajaran yang cukup banyak yaitu 7 dari 10 jam pelajaran dalam sehari. Hal tersebut menuntut guru untuk memiliki komunikasi yang baik selama proses pembelajaran. Agar guru senantiasa menciptakan lingkungan yang komunikatif di dalam kelas. Kejelasan guru dalam menyampaikan pesan/informasi akan bepengaruh pada pemahaman siswa (Rianantha \& Switri, 2015: 211).
Menurut Gapita (2016: 5) komunikasi dalam pendidikan merupakan unsur yang sangat penting kedudukannya. Bahkan ia sangat besar perannya dalam menentukan keberhasilan pendidikan siswa. Salah satu komunikasi dalam dunia pendidikan adalah komunikasi pembelajaran atau lebih dikenal dengan instruksional. Komunikasi instruksional dalam dunia pendidikan mempunyai pengertian sebagai komunikasi yang ditujukan kepada aspekaspek operasionalisasi pendidikan, terutama aspek pembelajaran sasaran, kredibelitas komunikator, situasi dan kondisi lingkungan, metode, dan termasuk bahasa yang digunaka sengaja dipersiapkan guru secara khusus untuk mencapai efek perubahan perilaku pada siswa (Yusup, 2010: 17)

Dalam mengetahui kemampuan komunikasi instruksional, (McCroskey dkk., 2004: 97) mengemukakan lima komponen yang dapat mengukur komunikasi instruksional di sekolah yaitu siswa, guru, kemampuan verbal dan nonverbal guru, persepsi siswa terhadap guru dan hasil instruksional. Lima komponen ini digunakan karena dapat menggambarkan lebih khusus kondisi komunikasi instruksional di sekolah dan bukan menggambarkan komunikasi instruksional secara umum. Lima komponen ini dapat mengukur komunikasi instruksional dalam teori maupun praktik. Karena instructional outcomes yang didapat berasal dari nilai ulangan akhir sekolah di mana dalam soal UAS terdapat soal teori dan praktik yang diujikan.

Berdasarkan pemaparan di atas mengenai kemampuan komunikasi guru dalam proses pembelajaran di sekolah, maka dilakukan penelitian dengan judul "Hubungan Komunikasi Instruksional dengan Hasil Belajar Ilmu Ukur Tanah di SMK Negeri 1 Jakarta" yang bertujuan untuk mengetahui seberapa besar hubungan komunikasi instruksional guru dengan hasil belajar siswa. 


\section{Identifikasi Masalah}

Berdasarkan uraian latar belakang yang telah dikemukakan sebelumnya, terdapat beberapa permasalahan yang dapat diidentifikasi sebagai berikut:

1. Guru belum maksimal dalam membangun komunikasi instruksional selama proses pembelajaran.

2. Rendahnya hasil belajar UTS ilmu ukur tanah siswa tahun ajaran 2017/2018.

3. Guru belum maksimal dalam mengajar dan mengorganisasikan pembelajaran di dalam kelas.

4. Guru belum maksimal dalam menggunakan media pembelajaran selama proses belajar.

5. Siswa kurang memahami ketika guru menerangkan pelajaran di kelas.

\section{Pembatasan Masalah}

Berdasarkan identifikasi masalah, maka penelitian ini hanya dibatasi pada:

1. Komunikasi instruksional pada mata pelajaran ilmu ukur tanah yang diukur dengan lima komponen menurut ahli yaitu McCroskey dkk.

2. Hasil belajar yang digunakan adalah hasil belajar UAS ilmu ukur tanah tahun ajaran 2017/2018.

\section{Rumusan Masalah}

Berdasarkan identifikasi masalah dan pembatasan masalah, maka masalah dapat dirumuskan sebagai berikut: Bagaimana relevansi materi ajar Mata Kuliah Prodi di Prodi PTB FT UNJ dengan materi ajar di SMK Negeri bidang keahlian Teknik Bangunan di Jakarta.

\section{Kegunaan Hasil Penelitian}

Adapun manfaat dan kegunaan dari penelitian ini adalah sebagai berikut :

1. Bagi siswa
Siswa dapat mengetahui pentingnya berkomunikasi dengan guru agar membantu siswa dalam memecahkan masalah dalam meningkatkan hasil belajar.

\section{Bagi guru}

Menjadi masukkan bagi guru tentang pentingnya komunikasi instruksional yang baik dalam proses pembelajaran guna meningkatkan hasil belajar siswa.

\section{Bagi Peneliti}

Membantu peneliti dalam menyelesaikan penelitian dan menambah wawasan pentingnya komunikasi instruksional guru dalam meningkatkan hasil belajar.

\section{Tinjauan Pustaka}

\section{Hasil Belajar Siswa}

Hasil belajar yang diperoleh siswa dapat berbeda-beda setelah ia menerima pengalaman belajarnya. Menurut Malik (2014: 49) bahwa hasil belajar adalah tingkat penguasaan yang dicapai oleh siswa dalam mengikuti proses belajar mengajar sesuai dengan tujuan pendidikan yang ditetapkan.

Menurut Arthur (2014: 26) hasil belajar merupakan perubahan pola tingkah laku yang didapatkan dari proses yang sistematis dari mulai perencanaan, proses dan evaluasi pembelajaran yang mempunyai peranan penting di dalamnya.

Sejalan dengan definisi di atas Menurut Arifin dalam Mulyono (2014: 90) bahwa hasil belajar merupakan kemampuan kecerdasan, keterampilan, dan sikap seseorang dalam menyelesaikan suatu hal. Hasil suatu pembelajaran (kemampuan, keterampilan, dan sikap) dapat terwujud jika pembelajaran (kegiatan belajar mengajar) terjadi.

\section{Mata Pelajaran Ilmu Ukur Tanah}

Salah satu mata pelajaran yang dipelajari di SMK khususnya jurusan bangunan adalah mata pelajaran ilmu ukur 
tanah. Dalam mata pelajaran ini, teori yang diberikan merupakan ilmu dasar sebelum melakukan kegiatan praktik pengukuran. Menurut Hadi (2014: 6) mengatakan bahwa

"Ilmu ukur tanah/survei dan pemetaan adalah sebagian kecil dari ilmu yang lebih luas, yang dinamakan ilmu geodesi. Secara ilmiah dapat diartikan menentukan bentuk permukaan bumi, sedangkan secara praktis yaitu mempelajari penggambaran sebagian besar atau sebagian kecil dari permukaan bumi, yang dinamakan peta".

Hasil belajar ilmu ukur tanah bisa didapatkan melalui ulangan akhir sekolah. Di SMK Negeri 1 Jakarta, ilmu ukur tanah yang di UAS kan memiliki indikator sebagai berikut:

1. Deskripsi ukur tanah/ survei pemetaan.

2. Ruang lingkup pekerjaan ukur tanah.

3. Alat ukur jarak dan alat ukur sederhana.

4. Pengenalan alat ukur optik.

5. Mengoperasikan alat ukur optik.

6. Pengukuran ketinggian dan hasil pengukuran.

\section{Komunikasi Instruksional}

Indikator-indikator yang digunakan untuk mengukur komunikasi instruksional guru dikembangkan melalui lima komponen yang dibuat oleh McCroskey dkk., dalam jurnalnya "Toward a General Model of Instructional Communication" yaitu student, teachers, teacher's verbal and nonverbal behaviors, student's perceptions of the teacher, dan instructional outcomes. Lima komponen tersebut akan dijelaskan sebagai berikut:

1. Student (Siswa) yang memiliki indikator prior learning,personality, temperament.

2. Teachers (Guru)

3. Teacher's Verbal \& Nonverbal Behaviors (Perilaku Verbal \& Nonverbal Guru)

4. Student Perceptions of The Teacher (Persepsi Siswa terhadap Guru)

5. Instructional Outcomes (Hasil Belajar)

\section{Tujuan Penelitian}

Adapun tujuan penelitian yang ingin dicapai dalam penelitian ini adalah untuk mengetahui hubungan komunikasi instruksional guru dengan hasil belajar siswa pada mata pelajaran ilmu ukur tanah di SMK Negeri 1 Jakarta.

\section{Metode Penelitian}

Penelitian ini merupakan jenis penelitian asosiatif kuantitatif. Penelitian asosiatif merupakan penelitian yang dilakukan untuk mencari hubungan antara variabel dengan variabel lainnya. Mencari hubungan sebab-akibat antar variabel.

Metode yang digunakan dalam penelitian ini adalah metode penelitian survei dengan pendekatan korelasional. Metode penelitian pada dasarnya merupakan cara ilmiah untuk mendapatkan data dengan tujuan kegunaan tertentu. Metode survei bertujuan untuk memperoleh data berdasarkan fakta di lapangan.

Dalam penelitian ini, peneliti menggunakan pendekatan kuantitatif. Pendekatan kuantitatif adalah penelitian dengan memperoleh data yang berbentuk angka (Sugiyono, 2003: 14). Angka-angka tersebut didapat dari hasil skor kuesioner yang telah diisi oleh siswa.

\section{Pembahasan Hasil Penelitian}

Berdasarkan pengujian yang telah dilakukan, didapatkan hasil dari pengujian tersebut yang dibuat dalam bentuk tabel sebagai berikut:

\section{Hasil Uji Statistik}

\begin{tabular}{|l|l|l|l|l|}
\hline No & $\begin{array}{l}\text { Jenis } \\
\text { Pengujian }\end{array}$ & Hasil & Syarat & Keterangan \\
\hline 1. & $\begin{array}{l}\text { Uji } \\
\text { Normalitas }\end{array}$ & 0,200 & $\begin{array}{l}\text { Sig } \geq \\
0,05\end{array}$ & $\begin{array}{l}\text { Berdistribusi } \\
\text { normal }\end{array}$ \\
\hline 2. & Uji Linieritas & 0,000 & $\begin{array}{l}\text { Sig }< \\
0,05\end{array}$ & Data Linier \\
\hline 3. & $\begin{array}{l}\text { Uji } \\
\text { Homogenitas }\end{array}$ & $\begin{array}{l}\text { Uji Koefisien } \\
\text { Korelasi } \\
\mathrm{r}_{\text {tabel }}(\mathrm{n}=80)= \\
0,220\end{array}$ & $\begin{array}{l}\text { Sig } \geq \\
0,05\end{array}$ & Data homogen \\
\hline $\mathrm{r}_{\text {hitung }}$ & $\begin{array}{l}\text { Hubungan } \\
\text { kuat atau tinggi }\end{array}$ \\
\hline
\end{tabular}




\begin{tabular}{|c|l|l|l|l|}
\hline 5. & $\begin{array}{l}\text { Uji Koefisien } \\
\text { Signifikansi } \\
\mathrm{t}_{\text {tabel }}=1,991\end{array}$ & 6,851 & $\begin{array}{l}\mathrm{t}_{\text {hitung }} \\
\geq \mathrm{t}_{\text {tabel }}\end{array}$ & $\begin{array}{l}\text { Terdapat } \\
\text { hubungan yang } \\
\text { signifikan }\end{array}$ \\
\hline 6. & $\begin{array}{l}\text { Uji Koefisien } \\
\text { Determinasi }\end{array}$ & 0,613 & $\mathrm{r}_{\mathrm{xy}}{ }^{2}$ & $\begin{array}{l}\text { Mempengaruhi } \\
37,6 \%\end{array}$ \\
\hline
\end{tabular}

Berdasarkan hasil perhitungan korelasi product moment pada tabel 4.10 dalam uji koefisien korelasi antara komunikasi instruksional dengan hasil belajar ilmu ukur tanah di SMK Negeri 1 Jakarta menunjukkan bahwa nilai $r_{\text {hitung }}$ lebih besar daripada $r_{\text {tabel }}(0,601>0,220)$. Dalam uji koefisien signifikansi juga menunjukkan bahwa nilai thitung lebih besar daripada $t_{\text {tabel }}$ $(6,851>1,6607)$. Sehingga dapat disimpulkan bahwa hipotesis penelitian $\left(\mathrm{H}_{1}\right)$ yang diajukan dapat diterima. Hubungan antara komunikasi instruksional dengan hasil belajar memiliki hubungan yang positif dan signifikan serta termasuk ke dalam kategori kuat.

Sebagai interpretasi, komunikasi guru dapat dikategorikan sebagai berikut:

\begin{tabular}{|c|c|}
\hline & KATEGORI \\
\hline $\mathrm{X}<$ Mean $-1 . \mathrm{SD}$ & Rendah \\
\hline Mean $-1 . \mathrm{SD} \leq \mathrm{X}<$ Mean $+1 . \mathrm{SD}$ & Sedang \\
\hline Mean $+1 . \mathrm{SD} \geq \mathrm{X}$ & Tinggi \\
\hline Dengan menghitung & mean dan
\end{tabular}

standar deviasi hipotetik dan empirik maka didapat hasil sebagai berikut:

\section{Mean Hipotetik}

$$
\begin{aligned}
\mu \quad & =1 / 2(\operatorname{imax}+\operatorname{imin}) \sum \mathrm{k} \\
& =1 / 2(5+1) 38 \\
& =114
\end{aligned}
$$

\section{SD Hipotetik}

$$
\begin{aligned}
\sigma & =1 / 6(\mathrm{Xmax}-\mathrm{X} \min ) \\
& =1 / 6(190-38) \\
& =25,3
\end{aligned}
$$

\section{Mean Empirik}

126,44

\section{SD Empirik}

33,94

Berdasarkan hasil tersebut dapat dikategorikan komunikasi instruksional guru termasuk dalam kategori sedang. Guru perlu meningkatkan kembali komunikasi selama pembelajaran agar hasil belajar yang optimal dapat tercapai.
Berdasarkan kriteria PAN, sebanyak $55 \%$ responden dinyatakan lulus atau sudah mencapai kriteria PAN. Sedangkan sisanya sebesar 45\% responden dinyatakan tidak lulus atau belum mencapai kriteria PAN. Tetapi, acuan norma yang didapat yaitu 63,8 masih dibawah standar KKM yang diterapkan yaitu 75. Hal ini menandakan bahwa tidak ada kemajuan kelas dalam UAS.

Hasil belajar juga dapat dikategorikan berdasarkan penilaian acuan patokan (PAP) yaitu berdasarkan KKM yang dipakai di sekolah. Nilai KKM untuk mata pelajaran ilmu ukur tanah pada kelas X DPIB yaitu 75. Hal ini berarti bahwa siswa yang memiliki nilai kurang dari 75 dinyatakan tidak lulus. Berdasarkan kriteria PAP didapatkan sebanyak 88,75\% siswa dinyatakan tidak lulus dan belum mencapai KKM sekolah. Sedangkan sisanya atau $11,25 \%$ responden dinyatakan lulus dan sudah mencapai KKM. Hal ini berarti, nilai yang di dapat siswa dalam ulangan akhir sekolah memiliki rata-rata nilai yang kecil dan jauh dari harapan. Terdapat perbedaan nilai antara PAN dan PAP yaitu sebesar sebesar 11,2. Maka, dapat dikatakan jika kelas belum mampu mencapai hasil belajar yang optimum, di mana kelas ataupun individu sebagian besar belum mampu mencapai nilai KKM yang diharapkan oleh sekolah yaitu sebesar 75 .

Pada indikator prior learning, 55\% responden menyukai mata pelajaran hitungan dan $42,4 \%$ responden menyukai pelajaran teori. Sebanyak $45 \%$ responden sering mengerjakan tugas sendiri dan $43,75 \%$ responden sering mengerjakan tugas secara berkelompok.

Pada indikator personality sebanyak $50 \%$ responden dapat menjalin hubungan yang baik dengan guru, sebanyak 50\% responden disukai oleh guru dan teman mereka, dan 50\% siswa sering termasuk orang yang mudah bergaul.

Pada indikator temperament sebanyak $52,5 \%$ siswa fokus mendengarkan ketika guru menerangkan pelajaran, sebanyak 55\%

Hubungan Komunikasi Instruksional ... - 35 Agung Ananto 
siswa mengerjakan tugas yang diberikan guru dengan sungguh-sungguh, dan 33,75\% siswa adalah orang yang periang.

Meskipun responden memiliki perbedaan dalam aspek yang disebutkan, hubungan, gaya belajar, dan emosi menjadi faktor penting ketika komunikasi instruksional guru berlangsung. Namun, sebagian besar responden tidak ada masalah dalam hal aspek yang telah disebutkan. Hal ini berarti seharusnya komunikasi instruksional guru dapat berlangsung secara efektif.

Pada indikator level of intellegence menunjukkan bahwa $40 \%$ responden mengatakan guru dapat menjawab kesulitan belajar responden, sebanyak 33,75\% responden mengatakan guru dapat menanggapi pendapat dan memberikan penjelasan kepada responden, sebanyak $43,75 \%$ responden mengatakan guru dapat memberikan contoh nyata dalam pembelajaran.

Pada indikator content knowledge menunjukkan bahwa $41,25 \%$ responden mengatakan guru dapat menguasai materi yang diajarkan kepada responden, sebanyak $43,75 \%$ responden mengatakan guru belum mampu menerangkan materi dengan jelas, dan sebanyak $41,25 \%$ responden mengatakan guru sudah menyampaikan materi dengan urut.

Pada indikator pedagogical knowledge menunjukkan sebanyak $56,25 \%$ responden menjawab bahwa guru tidak enak dalam mengajar, sebanyak $57,5 \%$ responden mengatakan guru dalam mengajar kadang mudah dimengerti, sebanyak 51,25\% responden menjawab guru jarang berinteraksi dengan responden selama pembelajaran didalam kelas.

Pada indikator communication competence menunjukkan bahwa sebanyak $43,75 \%$ responden menjawab guru belum dapat menjelaskan materi pelajaran dengan bahasa dan kata yang mudah dimengerti, sebanyak 55\% responden menjawab guru belum dapat menciptakan suasana yang menyenangkan di dalam kelas, dan 47,5\% responden menjawab guru menjelaskan materi pelajaran dengan tempo yang tepat.

$$
\text { Pada indikator experience }
$$

menunjukkan bahwa sebanyak 53,75\% responden menjawab guru menjelaskan materi pelajaran dengan lancar dan tanpa kesulitan, sebanyak $43,75 \%$ responden menjawab guru terkadang terampil dalam menggunakan media pembelajaran, dan $48,75 \%$ responden menjawab guru belum mampu memecahkan masalah dengan memberikan contoh-contoh nyata yang jelas.

Berdasarkan kemampuan guru dalam hal aspek yang disebutkan bahwa terdapat masalah pada guru dalam menggunakan bahasa dan kata-kata yang mudah dimengerti responden. Guru juga belum mampu memberikan suasana yang menyenangkan di dalam kelas dan guru belum maksimal dalam penggunaan media pembelajaran. Hal ini penting, karena kemampuan guru akan mempengaruhi proses komunikasi instruksional di dalam kelas.

Terdapat dua indikator dalam aspek teacher's verbal and nonverbal behaviors yaitu teacher's verbal behaviors dan teacher's nonverbal behaviors. Pada indikator teacher's verbal behaviors menunjukkan bahwa sebanyak 55\% responden menjawab bahwa guru jarang memberikan pujian kepada responden, sebanyak $46,25 \%$ responden menjawab bahwa guru masih belum dapat menyampaikan materi pelajaran dengan keras dan mudah didengar, sebanyak 47,5\% responden menjawab bahwa guru jarang memberikan motivasi dan nasihat kepada respondennya, dan sebanyak 42,5\% responden menjawab bahwa guru masih belum jelas dalam menyimpulkan poin-poin penting pelajaran.

Pada indikator teacher's nonverbal behaviors menunjukkan bahwa sebanyak 50\% responden menjawab bahwa guru kadang memberikan apresiasi kepada responden, sebanyak $48,75 \%$ responden menjawab bahwa guru kadang melakukan kontak mata pada saat responden berbicara, dan 36,25\% 
responden menjawab guru sering menunjukkan ekspresi tersenyum jika responden berhasil menjawab dengan benar.

Dalam hal ini, terdapat masalah dalam hal verbal guru, di mana guru masih belum dapat berbicara dengan suara yang jelas, jarang memberikan motivasi dan reponden belum mengerti yang dikatakan guru dalam pelajaran. Kemampuan verbal guru adalah hal yang penting dalam mendukung komunikasi instruksional selama pembelajaran berlangsung. Hal ini berarti guru masih memiliki kemampuan verbal yang belum cakap dalam proses pembelajaran.

Pada indikator credibility sebanyak $48,75 \%$ responden menjawab bahwa mereka percaya dengan apa yang disampaikan oleh guru mereka, sebanyak $51,25 \%$ responden menjawab bahwa guru belum mampu dalam berdiskusi di kelas, dan sebanyak 50\% responden menjawab bahwa guru belum mengajar dengan profesional.

Pada indikator task attractiveness sebanyak $61,25 \%$ responden menjawab bahwa guru tidak memiliki gaya mengajar yang menarik, sebanyak $58,75 \%$ responden menjawab bahwa guru belum maksimal dalam menyajikan media pembelajaran yang menarik dan komunikatif, dan sebanyak $51,25 \%$ responden menjawab bahwa guru terkadang memberikan perhatian kepada responden..

Dalam hal ini terdapat masalah dalam guru seperti guru tidak mampu dalam berdiskusi di kelas, guru belum mengajar dengan profesional, guru tidak menarik dalam mengajar, dan media pembelajaran yang disajikan belum menarik bagi responden. Kesan seperti ini yang dapat mempengaruhi pandangan responden terhadap guru. Kesan yang baik belum dapat diterima responden ketika pembelajaran, karena kesan ini bisa saja terus berada dalam diri responden dan akhirnya sulit bagi mereka untuk dapat menerima materi yang diberikan.
Dengan demikian, antara komunikasi instruksional dengan hasil belajar ilmu ukur tanah di SMK Negeri 1 Jakarta memiliki korelasi/hubungan yang kuat dan signifikan. Artinya, semakin efektif komunikasi instruksional yang dilakukan oleh guru maka semakin efektif pula proses pembelajaran di dalam kelas sehingga akan meningkatkan hasil belajar siswa pada mata pelajaran ilmu ukur tanah. Sebaliknya, apabila komunikasi instruksional yang dibangun tidak baik, maka akan berdampak pada menurunnya hasil belajar siswa.

Hasil tersebut sejalan dengan penelitian terdahulu yang dilakukan oleh Isnaini Indah Mawarni bahwa komunikasi guru-siswa memiliki pengaruh sebesar 94,7\% terhadap prestasi belajar siswa pada mata pelajaran IPS di MAN 15 Jakarta.

Ada beberapa hal yang harus ditingkatkan oleh guru dalam membangun komunikasi yang efektif. Guru harus mampu menanggapi dan memecahkan masalah atau kesulitan belajar siswa dengan memberikan penjelasan yang jelas dengan menggunakan kata-kata yang mudah dipahami dan dapat dimengerti siswa. Guru juga harus membangun komunikasi yang baik selama pembelajaran agar terjadi suasana yang menyenangkan di dalam kelas. Guru juga bisa memberikan contoh-contoh nyata dalam memberikan materi atau informasi yang diajarkan.

Selain itu, pujian, motivasi, semangat dan nasihat guru sangat diperlukan oleh siswa agar siswa menjadi terpacu dalam meningkatkan gairah untuk belajar, sehingga siswa dapat meningkatkan hasil belajar mereka. Guru harus bersikap profesional dalam mengajar, menggunakan bahasa dan kalimat yang mudah dimengerti siswa, dan mampu diajak untuk berdiskusi lebih dekat dengan siswa agar setiap kesulitan siswa mampu diselesaikan.

Adapun pengaruh variabel komunikasi instruksional terhadap hasil belajar yaitu sebesar 37,6\%. Sedangkan sisanya sebanyak $62,4 \%$ dipengaruhi oleh faktor lain yang tidak dihitung dalam

Hubungan Komunikasi Instruksional ... - 37

Agung Ananto 
penelitian ini. Oleh karena itu, faktor komunikasi instruksional tidak dapat diabaikan karena faktor tersebut berpengaruh dalam meningkatkan hasil belajar ilmu ukur tanah di SMK Negeri 1 Jakarta.

\section{Kesimpulan}

Berdasarkan hasil penelitian, maka dapat disimpulkan sebagai berikut: Bahwa untuk meningkatkan hasil belajar siswa dibutuhkan komunikasi instruksional guru yang baik dalam proses pembelajaran, seperti menggunakan bahasa dan kata yang mudah dipahami, menggunakan suara yang keras dan dapat didengar ketika mengajar, memberikan motivasi dan apresiasi kepada siswa, menggunakan media pembelajaran dengan efektif, dan membangun persepsi yang baik bagi siswa.

\section{Saran}

Adapun saran yang peneliti ajukan dalam penelitian ini, agar dapat bermanfaat bagi guru, siswa, ataupun pihak lain dalam meningkatkan hasil belajar siswa pada mata pelajaran ilmu ukur tanah di SMK Negeri 1 Jakarta adalah sebagai berikut:

1. Guru

Guru hendaknya lebih meningkatkan kembali kemampuan berkomunikasi khususnya komunikasi instruksional baik secara verbal maupun nonverbal, agar terjadi pemahaman yang sama antara guru dan siswa sehingga dapat menciptakan suasana pembelajaran yang menyenangkan dan efektif. Guru juga hendaknya lebih mengajak lagi siswa dalam berdiskusi atau berinteraksi selama pembelajaran berlangsung agar terjadi komunikasi dua arah atau multi arah sehingga siswa ikut terlibat aktif dalam pembelajaran.

\section{Siswa}

Siswa hendaknya bisa lebih aktif lagi dalam mengikuti proses pembelajaran, misalnya dengan berkonsentrasi penuh ketika guru menerangkan materi di dalam kelas, mencatat poin-poin penting materi yang dijelaskan guru dan lebih aktif dalam bertanya atau berdiskusi dengan guru. Agar guru bisa terbiasa dalam berkomunikasi di dalam kelas.

3. Peneliti Selanjutnya

Dalam penelitian ini, hanya terbatas pada komunikasi instruksional saja. Oleh karena itu, diharapkan peneliti selanjutnya dapat meneliti faktor lain yang dapat mempengaruhi hasil belajar siswa.

\section{Daftar Pustaka}

Arthur, R. (2014). Pengukuran Acuan Terpadu (PAT) Dalam Mengukur Kompetensi Dalam Bidang Teknik Sipil, III(2), 25-32.

Gapita, rafi syas. (2016). Komunikasi Instruksional Pengasuh Dalam Proses Belajar Mengajar Pada Program Tahfidz Quran di Pondok Pesantren Umar Bin Khatab Pekanbaru, 3(2), 115.

Hadi, Nugroho Muhammad Sofwan (2014). Ukur Tanah Semester 1. Jakarta: Kementrian Pendidikan RI.

Malik, A. (2014). Fungsi Komunikasi Antara Guru dan Siswa dalam Meningkatkan Kualitas Pendidikan (Studi Kasus Proses Belajar Mengajar pada SMP Negeri 3 Sindue). Jurnal Interaksi, 3(2), 168-173.

McCroskey, J., Valencic, K. M., \& Richmond, V. P. (2004). Toward a General Model of Instructional Communication, 52(3), 197-210.

Mulyono. (2014). Pengaruh Komunikasi Guru Dalam Mengelola Kelas Terhadap Prestasi Belajar PkN, 2(1), 90-103.

Rianantha, \& Switri. (2015). Hubungan Disiplin Belajar Terhadap Hasil Belajar Siswa Kelas IV SDN 18 Banda Aceh, 2, 211-243.

Rosita, R., \& Alfarisa, F. (2015). Pendidikan Profesi Guru (PPG): Strategi 
Pengembangan Profesionalitas Guru. Prosiding Seminar Nasional, 4(1995), 671-683.

Sanjaya. (2016). Evaluasi belajar peserta didik (siswa), I(36), 90-99.

Sugiyono. (2013). Skripsi, Tesis, dan Disertasi. Bandung: Alfabeta.

Yusup, P. M. (2010). Komunikasi Pendidikan dan Komunikasi Instruksional. Jakarta: Bumi Aksara. 